\section{Reading Re-readings}

Alistair Davies and Alan Sinfield (ed.): British Culture of the Postwar: Introduction to Literature and Society 1945-1990 (London, New York: Routledge, 2000)

When actually was 'the postwar'? This is the question the editors put at the very beginning of the book, and, of course, there is no precise answer to it, just as in any other case when you try to define a certain period in time. One thing is sure though, that the postwar period began after World War II, in 1945, when people of many different countries and nations went to the streets to celebrate the end of suffering and fear. What seems to be problematic is to define the end of the period.

What brings the period to an end? The Conservatism of the Thatcher Government or the election of the Government led by Tony Blair? Or, as the editors remark, "maybe such views are (typically) parochial, and international developments are more important: the ending of the Cold War, or the pressures towards globalisation" (p. xi).

The contributors' aim in this book is not to draw borderlines but to offer different standpoints, often ones which show things from a point of view that, for some reason, has re- mained hidden throughout these years. "In discussing the literature, film and visual arts of the past fiftyfive years," the editors claim, these essays "discover radical discontinuities and underlying continuities" (p. xi).

"To write of 1960 in the mid 1990s is to be conscious of trying to define a legacy whose implications and ramifications are far from clear. We are still living the harvest of the sixties and to that extent we cannot entirely bring its meaning of significance to conscious articulation: to declare that it was indubitably bad harvest of an unusually rich one seems premature," writes Patricia Waugh in her excellent book The Harvest of the Sixties. "To write an account of a historical period through which one has lived is in some sense to write an autobiography where the past and future are necessarily and often mysteriously shaped by the writer's present situation," she continues. "This is also confirmed by Alan Sinfield: "This is inevitably a personal book [...] I am re-writing, in large part, my own intellectual history and configuration. ${ }^{2}$

I think reading an account of a historical period through whicb the reader has lived is almost as exciting as writing it; it is like re-thinking, rereading our own history both in the narrowe: and wider sense of the word. Besides the attempt of trying to work 
up what has happened in the last ten years, the desire to re-think things was probably another important factor that has made the two editors, Alan Sinfield and Alistair Davies compile another postwar-book to which they also contributed in the form of three essays. The editors as well as the six other contributors are from the Universities of Sussex and Cambridge. The book, consisting of four parts, presents the most interesting problems of British culture at the end of the $20^{\text {th }}$ century: the meaning and problems of post-imperialism, the effects on culture of a shift from a welfare state to free market, Britain's relationship to the continent and Americanisation, and the connection between consumption and cultural institutions. The essays reflect refreshing, new approaches to the cultural history of postwar Britain in the stimulating spirit of Sussex. Each part is introduced with a short summary of the most important historical events of the period. These introductions are not only data that are piled up but each is a thorough-going essay which helps to understand the interaction between art and society; put together they would serve as a short but very informative textbook in British Studies complemented by an excellent bibliography on related topics at the end of every part.
The first two chapters examine the concept of post-imperialism from two points of view. Siobhán Kilfeather's "Disunited Kingdom" begins with a question which emerges in the reader when (s)he looks at the cover of the book, namely, what exactly is meant by the expression "British culture." The difficulties begin with naming. "It is actually impossible to name and describe something called 'British culture," Kilfeather writes (p. 10.); but it is also difficult to define and locate Britain itself. In naming the country there are two different modes in use nowadays: "Brizain and Ireland" or "the archipelago." She chooses the name "Celtic" (!) in her essay for the Irish, Scots and Welsh. Writing about national consciousness, she presents the way Celtic peoples have made the way in self-assertion since the " 40 s to the present day from "parochialism," which meant the self-assurance of the metropolitan culture versus the "provincialism" of the country where no judgement was even made unless first it was heard what the metropolis had said, through Seamus Heaney's immense influence which made the country observations valid and respected, to the present when it is 'chic' to be Celtic. Irish culture, for example, is very popular among young people all over Europe, all over the world today - one can think of 
the success of $U 2$, Sinead O'Connor, or the popularity of Irish folk music.

If the meaning of being British is problematic for natives, the situation of migrants is even odder: in her essay "Migration and Mutability," Minoli Salgado explores the problems of migration in post-imperialist Britain through discussing the consequences of the so-called Rushdie-affair and tries to define Rushdie's place in Britain and his place among migrants. The term "twice born" in Salgado's essay refers not only to the Hindu ceremony of initiation but also signifies the migrant position. As she explains, the Hindu term does not mean a rebirth but rather a split subjectivity which is characteristic of a migrant's personality; in this way she relates Rushdie's point of view to that of the famous post-structuralist critic, Homi Bhabha. Salgado also reminds us that migration is not a mere metaphor but a condition experienced by millions in the world. At the same time, of course, there are numberless varieties; one should not forget the difference between Rushdie's élite condition and those who have left their homes because of economic necessity. What gives the essay special weight is that her reading of migration "is in fact a migrant's reading, containing many of the concerns and doubts of one whose mixed cultural affiliations both enable and require the mutability of multiple subject positions [...] but one which prioritises a migration post-colonial concern with the issue of agency" (p. 35).

How is writing influenced by the shift from a welfare state to free market? Both essays in the second part of the collection address the question from a different point of view. Margaretta Jolly examines what the term "feminist writing" means today, while Alan Sinfield highlights the connection between literature and sexual identity through a comparison of two novels by Angus Wilson and Alan Hollinghurst.

Jolly's "After Feminism" begins with the statement that despite the general acceptance of the idea that several starting points may be used in the definition of postwar British fiction, the legacy of the 'old' canon of largely male, Anglo-British writing is still dominant. She mentions some recent critics who have written the alternative history of British fiction with a focus on women authors. (See for example F. Alexander, Contemporary Women Novelists; T. Cosslett, Women Writing Childbirth: Modern Discourses of Motherhood; M. Ezel, Writing Women's Literary History; L. Sage, Women in the House of Fiction: Postwar Women Novelists.) However, Jolly's aim is not by any means to 
exchange the present canon for a homogeneous women writers' canon. On the contrary, she asserts that hardly any consistent separation between male and female literary interests can be detected. In her essay, she is concentrating on Pat Barker, who, she believes, "bridges feminist and mainstream literary interests in ways that make her difficult to categorise" (p. 59). She compares Barker to Penelope Lively, and draws the conclusion that, though Barker is aesthetically less innovative (she never breaks the frame of time or space, almost constantly uses a third-person narrator), her writing within a social realist tradition is still more suitable to reveal the problems of social identity, the relationship between gender and history than Lively's postmodernism. Baker, she believes, is "an apt prism through which to consider the current interplay between feminism and writing" (p. 78).

Comparing Angus Wilson's Hemlock and After to Alan Hollinghurst's The Swimming Pool Library, in his "Culture, Consensus and Difference" Alan Sinfield - who belongs to the British Marxist tradition and in my view has written one of the most stimulating chapters of the book illustrates the idea he is basically concerned with: what happened to the consensus (the agreement after the war that pre-war conditions should be changed by a welfare society where "good things" - job, pension, education, healthcare and, what is in focus in the essay, "good culture" - "which had been enjoyed customarily by the leisure classes, were now to be available to everyone" [p. 89]), why should it rather be called an "aspiration" than an achievement, and what are the consequences of this miscarriage. Sinfield draws two important conclusions. First, literature has lost its earlier status: Wilson's belief in the possibility of the state's support of young artists in new forms proved to be an illusion. While Wilson was assured that it was clear for everybody what literature was, Hollinghurst's book offers different kinds of readings. Relying on received ideas concerning what literature is supposed to be, it is impossible to decide if The Swimming Pool Library is literature or pornography. Sinfield's aim here is not to analyse the possibilities or impossibilities of making this distinction these days, but to find the reason for this - as he calls it - "shift from the consensual, inclusive cultural authority" (p. 99). In his view the shift is due to the victory of market ideology, which has forced literature out of the state sector into the world of commerce. Secondly, he alerts the reader to a "rrap": out-groups are often util- 
ised by market forces. In this case, their exoticism serves only as a bait. One should not think that their being supported by different marketoriented people or groups means that being different is accepted; the success of a gay pop group or a lesbian writer does not mean that the struggle for the right of being different is won.

In the third section of the collection of essays Britain's connection to the countries of the continent and the problem of Americanisation is discussed in two chapters, both by Alistair Davies. "Had matters taken a different course, Brighton and Hove (where some of the earliest British film-makers were based) rather than Hollywood might now be the centre of the world cinema" (p. 110), Davies claims in his essay "A Cinema InBetween." He compares several possible readings of the history of postwar British film. It is clear that the moment of Hollywood's victory over British cinema (after World War I) was significant for the British film industry; with American domination, as Davies asserts, British directors and producers (and maybe not only the British) have had two options: to compete with Hollywood by actually "copying" it, or to contrast the "realism" of the British cinema with the "tinsel" of Hollywood. Davies also examines the relationship between
British and other European cinemas, and assesses the British avant-garde. $\mathrm{He}$ seems to suggest that Greenaway, Jarman, Sally Potter and Terence Davies' names are lost among directors trying to come up to the market's expectations with making films that depended heavily upon the use of national stereotypes - like, for example, Crichton's A Fish Called Wanda, or Newell's Four Weddings and a Funeral. Though Hollywood is still dominant on the market, the British cinema in the 1990s, Davies claims, "has been one of the truly international spaces of postwar British culture where music, literature and the visual arts have been able to combine freely and creatively" (p. 122).

Davies' chapter on Auden and postwar British culture, "Faltering at the Line," is a very thought-provoking presentation of the newest reading of Auden that makes a break with the tradition of considering Auden an apostate both in politics and poetics, a tradition originally established by Larkin and the Movement Poets. In 1939 Auden left for America, and remained there throughout the war. He returned to Britain only for occasional visits after 1945, and for his (earlier) friends he remained the propagandist of the American way of life. Though he pursued the question of the differences and similarities be- 
tween America and Europe with a great expertise both in his articles and poetry (which brought him immediate success in America), it was never enough to regain his reputation in England. By throwing a different light on some of the well-known poems (like, for example, In Memory of W.B. Yeats; Spain, 1937; In Memory of Sig. mund Freud), Davies' essay presents a poet whose "questioning of his own authority" during the postwar time and his constant resistance to his contemporaries' attitudes to the situation of postwar Britain and Europe made him appear peculiar in the eyes of his contemporaries. Auden rejected most radically the idea of restoring Europe by reviving the classical-imperialpatriarchal basis, where one hears "the weeping of a Muse betrayed," as he writes in his "Secondary Epic." In conclusion, the author says that Auden's postwar poetry includes constant self-reflection and selfquestioning. Davies shows us a deeply interesting standpoint from which it is possible to read the American Auden and to drop the "national culture of conceit" (p. 137). He seems to suggest that what by Auden's revaluation one can gain is an excellent vantage point for which one can better see the outlines of post-modern poeiry.

The 1940 s and 1950 s are very rich years if one considers how many im- portant institutions were founded at those times: the Opera, the Edinburgh Festival and the BBC are there to mention. The essays in the fourth part examine the development (?) in the connection between "Class, Consumption and Cultural Institution" in the fields of the arts and the theatre.

In "Art in Postwar Britain," Nanette Aldred has chosen a new way of approaching postwar British art in her essay. She concentrates on the history of The Institute of Contemporary Arts and presents its postwar role by giving particular attention to a commission held in 1953 and two exhibitions (When Attitudes Become Form in 1969 and The Thin Black Line in 1985) which were not necessarily the most well attended and widely spoken of events, but whose roles seem to have been significant in contemporary art. She believes that this approach allows us "to consider art works and events in a theoretical context at some key moments in British visual culture" (p. 147). Through pre. senting the story of the commission titled The Unknown Political Prisoner she explores the most basic difficulties of the art of the 1950 s which made it impossible to build Reg Butler's prizewinning monument planned to be set up in West-Berlin, namely the lack of funding, as well as Britain's need to re identify itself against American art, 
and the consequences of the Cold War. With this method, she is leading the reader through the sixties, seventies and eighties just as though she were a guide, highlighting many questions and disclosing information which usually are veiled from the spectator on a usual visit to an exhibition. She also presents the position of London in these decades comparing it to that of other European cities. As she writes, her aim is to show British art in relation to that of Paris and New York, avoiding "to create an underlying notion of "Britishness" (p. 164).

The issues raised at the beginning of Drew Milne's article, "Drama in the Culture Industry: British Theatre After 1945," pronise an exciting essay not only on the problems of British, but of the whole European theatre. However, the author does not seem to go much beyond raising questions on the most exiting possibilities of redefining theatre in his article. One of the most rewarding issue raised is what one can actually "do" with the theatre in the age of "dramatised society." Milne borrows Raymond Willians' term to describe ou life, where "drama through television, radio ard film, is now a rhythm of everyday life" (p. 172). The concept of drama should be rethought in this light, Milne assumes, and the theatre mirt define itself against the media and find its place in the "culture industry" (a term which was first used by Adorno). $\mathrm{He}$ compares Lawrence Olivier's and Kenneth Branagh's careers to illustrate how the "culture industry" can be influential as a force defining theatre. While Olivier's shift from stage to cinema is "emblematic of the social contradictions in theatre's struggle for independence as a significant cultural form," Branagh's attempt, "to finesse the differences of stage acring and film," Milne says, "is symptomatic of an increasing gulf between the residual formations of verious bourgeois theatre and the aesthetics of the cinema box office" (p. 174).

Andrew Crozier's essay, which constitutes the last contribution to the collection, bears a rather telling title: "Resting on Laurels." Crozier offers here an elaboration on his argument published in 1983, namely, that the canon of postwar British poetry developed in the '50s and '60s had Larkin, Hughes and Heancy as its cardinal representatives is still with us. He asserts that the features which make a poem fit the canon are still the same in the $1990 \mathrm{~s}$. With reference to rwo poetry anthologies editcd in the 1990 s (The New Poetry by Hulse, Kennedy and Morley and its complementary volume, Nore Relations: The Re- 
fashioning of British Poetry 1980-1994 the history of postwar Britain which by Kennedy), Crozier warns us that reflects the main characteristics of despite all the lip service being paid to cultural trends in the continent and alternative views we still have the the US in this age of globalisation. same prejudices and exclusions that characterised the authoritative views of the ' 50 s and ' 60 s.

On the whole, British Culture of the Postwar is a splendidly constructed book; it is a very useful read not only for students and academics, but also for all those who want to understand their own cultural plight by re-reading

\section{NOTES}

${ }^{1}$ Patricia Waugh. The Harvest of the Sixties: English Literature and Its Background, 19601990. Oxford: OUP, 1995, p. 2.

${ }^{2}$ Alan Sinfield. Literature, Politics and Culture in Postwar Britain. Oxford: Blackwell, 1989, p. 4. 